\title{
Assessment of New Ecotechnological Measures to Restore the Eutrophicated Lake
}

\author{
V. Prithiv Raj*, T. Ilakiya, E. Parameswari and V. Davamani \\ Horticultural College and Research Institute, \\ Tamil Nadu Agricultural University, Periyakulam, India - 625604 \\ *Corresponding author
}

\section{Keywords \\ Bioaugmentation, composting, eutrophication and pollutant degradation}

Article Info

Accepted:

12 February 2020 Available Online: 10 March 2020

A B S T R A C T

Water hyacinth (Eichhornia crassipes) is one of the most troublesome weed in the aquatic systems. It causes severe environmental and economical problems in many tropical and subtropical parts of the world. Studies were conducted on assessment of new ecotechnological measures to restore the eutrophicated lake from noxious aquatic weed. The first phase of the experiment was conducted by composting the water hyacinth biomass with crop residues. Analytical results of the composting study revealed that $T_{5}$ (Water Hyacinth + Crop Residue + Cow dung (1:1:1) + Pleurotus + Eudrilus euginae) had the higher total nitrogen value of $0.93 \%$, total phosphorous $1 \%$ and total potassium $1.10 \%$. The phytotoxicity studies showed that $\mathrm{T}_{5}$, recorded maximum germination percentage $(100 \%)$ and greater vigour index compared to other treatments. The second phase of the experiment was, native microorganisms isolated from the water samples of the eutrophicated lake was identified as Xanthomonas sp., Pseudomonas fluorescens, Enterobacter sp., and Bacillus sp. were mass multiplied and used for pollution degradation. The best culture for pollution reduction was observed to be EL3 (P. fluorescens). It has recorded $75.19 \%$ reduction of total nitrogen, $88.05 \%$ reduction of total phosphorous and $100 \%$ reduction in heavy metals. Hence, the potential of this organism may be utilised through biostimulation and bioaugmentation process to restore the eutrophicated lake.

\section{Introduction}

Water is the basic entity on which our entire human life relies on but currently facing a threat of scarcity. On the other side, the native water resources are now-a-days adversely affected by a variety of aquatic weeds. Water hyacinth (Eichhornia crassipes), the most important world's noxious fresh water plant has the ability of rapid proliferation and congested growth leading to eutrophication, one of the most widespread environmental problems of inland waters. It grows over a wide variety of wetland types from lakes, streams, ponds, waterways, ditches and backwater areas covering approximately 2,00,000ha (Murugesan et al., 2005).In many places, the weed poses serious challenges in 
navigation, irrigation and power generation. It reduces the flow capacity of water by approximately 40-95\%; thus decreasing the water availability to agriculture. The dense mats of these weeds reduce the dissolved oxygen levels in water leading to the death of aquatic life. In addition, it provides habitat conducive for vectors of malaria, causes skin rashes and host agents of amoebic dysentery and typhoid.

The explosive nature of water hyacinth growth and its related problems have called for serious efforts to control its spread. Management strategies include physical, chemical, biological or integrated approaches (Abbasi and Ramasamy, 1999). As attempts to control the weed have caused high costs and labour requirements, leading to nothing but temporary removal of the water hyacinths. Apart from Tamil Nadu, some of the irrigation and hydroelectric projects in the country like Nagarjunasagar project in Andhra Pradesh, Tungabhadhra project in Karnataka, Kakki and Iddiki reservoirs in Kerala are suffering from massive growth of aquatic weeds.

Hence, a considerable research effort is needed torestore the eutrophicated lake and getting worth out of waste. Considering the present agricultural scenario which thrust uponthe environmental safety and security, the present investigation has been carried out to overcome the foresaid lacuna with the objective of studying the efficacy of composting techniques to generate compost out of water hyacinth. In addition to that, isolation and characterization of native microflora from the eutrophicated lake and then assessing the efficacy of isolated microorganisms for pollutant degradation.

\section{Materials and Methods}

The present investigations were made during 2016-2017 to restore the eutrophicated lake of
Lakshmipuram in Theni district of Tamil Nadu.

\section{Collection and characterization of samples}

The water hyacinth biomass and water sample were collected from the eutrophicated lake and analysed for their physico-chemical and biochemical properties. Physico-chemical properties like moisture content, $\mathrm{pH}$, Electrical Conductivity, total organic carbon, total nitrogen, phosphorus and potassium were analysed as per the standard methods(APHA, 1980).

\section{Production of quality manure out of water hyacinth biomass}

The water hyacinth based composting has been carried out along with locally available farm wastes viz., crop residue, leaf litter and cow dung. Five treatments were carried out with four replications under Randomized Block Design. The treatment details are as under.

$\mathrm{T}_{1}-$ Water Hyacinth + Crop residues $(1: 1)$

$\mathrm{T}_{2}-$ Water Hyacinth + Crop Residue + Cow dung (1:1:1)

$\mathrm{T}_{3}-$ Water Hyacinth + Crop Residue + Cow dung $(1: 1: 1)+$ Pleurotus

$\mathrm{T}_{4}-$ Water Hyacinth + Crop Residue + Cow dung (1:1:1) +Eudriluseuginea

$\mathrm{T}_{5}$ - Water Hyacinth +Crop Residue+ Cow dung (1:1:1) + Pleurotus + E.euginea

After the maturation of compost, its maturity was tested with indices and germination study was also conducted by suing tomato and cluster bean seeds in the laboratory to assess the compost efficacy and test the phytotoxicity. The various parameters viz., root length, shoot length, germination percentage and vigour index has been calculated. 
Isolation and characterization of native microflora from the eutrophicated lake

The microbial populations of different groups were enumerated from the water sample using the standard serial dilution and plate count technique (Jenson, 1968)using appropriate media for bacteria, fungi and actinomycetes. These microbial isolates were identified using morphological, cultural and biochemical tests as per the standard manual (Bachanan and Gibbons, 1974).

\section{Assessing the pollution reduction potential of isolated microorganisms}

Series of batch experiments were conducted by using identified elite microbial cultures to reduce the pollution loads of eutrophicated lake and to assess its efficacy on pollution reduction. The identified microorganisms were further mass multiplied under laboratory condition. The broth for each culture was prepared and taken in ten different conical flasks for ten different cultures to grow and it was inoculated with respective cultures. Ten treatments and three replications were made as per the Completely Randomised Design (CRD). The physico-chemical evaluation of various parameters like $\mathrm{pH}$, Electrical Conductivity, Biochemical Oxygen Demand, Chemical Oxygen Demand, Total Suspended Solids, Total Dissolved Solids and heavy metals were taken into account for bioremediation.

\section{Results and Discussion}

\section{Characterization of substrates}

The physico-chemical characters of all the substrates (water hyacinth, cow dung and crop residue) were analysed and the results were compared. The details of the parameters evaluated have been shown in Table-1. The determination of chemical parameters of the initial feed revealed that water hyacinth possessed higher total nitrogen $(0.91 \%)$ and phosphorus $(0.88 \%)$, whereas crop residues recorded higher total $\mathrm{K}(1.74 \%)$ and $\mathrm{C}: \mathrm{N}$ ratio (196.36). Studies of Batham et al., (2014) revealed that while co-composting of materials with high $\mathrm{C}: \mathrm{N}$ ratio, cow dung will be highly useful to narrow down the $\mathrm{C}: \mathrm{N}$ ratio. Relatively low $\mathrm{C}: \mathrm{N}$ ratio of water hyacinth showed that it was nutrient rich substrate essential for the feedstock to be decomposed.

\section{Composting}

Changes in the chemical characteristics, stability and maturity of the composting mixture with time were studied by collecting and analysing the samples at periodical intervals of $0,20,40,60$ Days after sowing (DAS). The details about the changes in $\mathrm{pH}$ and EC of compost during composting are furnished in Table-2. Electrical conductivity is the measure of the soluble salt content of compost. The electrical conductivity of compost samples varied from 0.74 to 0.94 $\mathrm{dSm}^{-1}$ during initial compost samples. Among the treatments, $\mathrm{T}_{5}$ (water hyacinth + crop residue+ cow dung $(1: 1: 1)+$ Pleurotus $+E$. eugeniae) recorded higher Electrical Conductivity.

Among the stages, 40 days old compost recorded higher EC, which might be due to high initial microbial activity and mineralization (Campell et al., 1997). But in later stages, as the humification process proceeds, the humic fractions may become complexed with the soluble salts in turn decreasing the amount of mobile free ions (Rao et al., 2007). With respect to $\mathrm{pH}$, initial $\mathrm{pH}$ of the compost ranged from 7.0 to 7.9 during the sampling period. Significant changes in $\mathrm{pH}$ were noticed in all the treatments during composting. Among the various treatments, $T_{5}$ recorded the mean 
minimum $\mathrm{pH}$ of 7.25 whereas the mean maximum $\mathrm{pH}$ of 7.78 was recorded in $\mathrm{T}_{1}$.

The degree of decomposition of organic matter during composting process has often been used to define compost maturity and stabilized organic matter. In the present investigation, the total organic carbon content was found to be reduced in all the degradation stages of compost samples (Fig.1). Among the treatments, $\mathrm{T}_{5}$ recorded the minimum total organic carbon, which might be due to the effective role of degraders (microflora and macro fauna). The results were found to be consonance with the findings of Nallathambi and Marimuthu (1993), who reported that Pleurotussppwere highly efficient in reducing the organic carbon content.

During composting process, microorganisms oxidize organic matter and release essential minerals for plants such as nitrogen, phosphorus, and potassium (Table-3). Nitrogen is an important nutrient for composting process since it determines the microbial population. Comparing the composting stages, there was a significant increase into talk jeldahl nitrogen (TKN) as procession of composting process, which might be due to the breakdown of the proteins among the treatments; $\mathrm{T}_{5}$ showed higher TKN which might be due to vibrant role of organisms.

Similar results were reported by Suthar (2007), who reported that earthworms enhanced the nitrogen levels of the substrate during digestion in their gut adding their nitrogenous excretory products, mucus, body fluid and enzymes in composting process .Phosphorous $(\mathrm{P})$ is also an important nutrient for plant growth. In the present investigation, the total $\mathrm{P}$ was higher in the compost harvested at the end of the experiment compared to that of the initial substrate, but water solubility of phosphorous decreases with humification (Elango et al., 2009). Among the treatments, $T_{5}$ showed higher total phosphorous compared to other treatmental combinations.

In addition, this increase might be due to the earthworm gut enzyme phosphatases and "P" solubilizing microorganism present in worm casts, which is inconsonance with the findings of Suthar(2007). The potassium concentration varies from 0.86 to $0.91,0.91$ to $1.21,1.12$ to 1.45 and 1.14 to1.34\% during initial, 20, 40 and 60 days old compost samples, respectively. This might be buttressed due to the production of acids by the microorganisms and enhanced mineralization rate through increased microbial activity during the composting process.

\section{Maturity indices of compost}

Qualitative tests such as starch iodine tests and sulphide tests were performed to assess the maturity of the compost. The starch iodine test resulted in a yellow coloured solution without any precipitate for all the treatments. For sulphide test, absence of black colour was observed in all the treatments (Table 4).Humic substances present in compost are good indicators of compost maturity. Higher values of humic acid, degree of humification and polymerization ratio are good indices of compost maturity and highest values were recorded in $T_{4}$ followed by $T_{5}$. The minimum polymerization ratio value was recorded in $T_{4}$ (0.72) and the maximum value was observed in $\mathrm{T}_{2}(0.85)$.

\section{Phytotoxicity assay}

Seed germination and plant growth bioassays are the most common techniques used to evaluate compost phytotoxicity (Kapanen and Itavaara, 2001). In the present study, it was observed that the compost from all the treatments has no inhibitory effect on germination of tomato and cluster bean seeds. 
The results showed that $T_{5}$ showed higher length of seedlings (root + shoot), germination percentage $(100 \%)$ and vigour index followed by $\mathrm{T}_{3}$ with water hyacinth + crop residue+ cow dung (1:1:1) + Pleurotus(Table-5).

This shows that the compost derived from water hyacinth in all the combinations were free from heavy metals, ammonia, salts and low molecular weight organic acids (Batham et al., 2014). Further, it was concluded that water hyacinth enhances nutritive value of final compost and if blended in appropriate quantity with other farm wastes could it accelerate the degradation process.

\section{Characterization of native microbial isolates}

The microbial population viz., bacteria, fungi and actinomycets etc. are characterized. Out of these, bacterial isolates were majorly isolated from the eutrophicated lake and identified based on the morphological and biochemical characterization (Table 6). Ten bacterial cultures were isolated and most of these cultures were gram negative and round. Except 2 bacterial cultures all others are gram positive and wrinkled.

All were found to have rod shaped colonies, except one culture which was found tohave cocci shaped colony. In glucose, starch and lactose analysis, some of the culture showed both acid and gas production. All the bacterial cultures are having positive result in both citrate utilization and catalase activity. Starch hydrolysis, Gelatin hydrolysis and Indole production tests most of the cultures are shown positive results and some of the cultures shown negative results. Based on this morphological and biochemical characterisation bacterial isolates were identified as Pseudomonas sp, Pseudomonas fluorescens, Bacillus sp, Xanthomonas sp. and Enterobacter sp.

\section{Pollution reduction}

The isolated bacterial cultures were mas multiplied and utilised for assessing the pollution reduction potential in the eutrophicated lake. The physico-chemical characteristics of the effluent before and after inoculation of all the cultures were tested and results are presented in Fig. 2 and 3.

Before inoculation of microbial cultures, the $\mathrm{pH}$ and $\mathrm{EC}$ was found to be 8.12 and 1.21 $\mathrm{dSm}^{-1}$ respectively which underwent a decline to 7.62 and $0.51 \mathrm{dSm}^{-1}$ withinoculation of EL3 culture. The BOD and total $\mathrm{N}$ of the eutrophicated water was 234 and $32.24 \mathrm{mgL}^{-1}$ which down trends to 66 and $7.1 \mathrm{mgL}^{-1}$ with the inoculation of EL8 and EL1 respectively.

Similarly, the initial COD, TSS and TDS before inoculation was found to be 420,258 and $780 \mathrm{mg} \mathrm{L}^{-1}$ which reduced to 142,20 and $120 \mathrm{mg} \mathrm{L}^{-1}$, respectively with introduction of microbial culture EL3, whereas the culture EL6 reduced the total P to 1.5 from $8.37 \mathrm{mg}$ $\mathrm{L}^{-1}$ (Initial).

The heavy metals such as $\mathrm{Cr}, \mathrm{Cd}, \mathrm{Pb}$ and $\mathrm{Ni}$ of the initial water was found to be $0.02,0.05$, 0.05 and $0 \mathrm{mgL}^{-1}$ which decreased drastically to below detection limit by the cultures of EL3,EL5,EL6,EL7,EL8 and EL9. This is in line with the findings of Parameswari (2009), who reported that Pseudomonas fluorescens has the ability to grow under wide variety of carbon sources and able to manage heavy metals and other pollutants through its both intracellular and extracellular mechanisms. 
Table.1 Characteristics of substrates used for composting

\begin{tabular}{|l|c|c|c|}
\hline \multicolumn{1}{|c|}{ Parameters } & Water hyacinth & Cow dung & Crop residues \\
\hline pH & 7.2 & 8.8 & 7.4 \\
\hline Total organic carbon (\%) & 40.2 & 39.4 & 43.2 \\
\hline Total Kjeldahl'N' (\%) & 0.91 & 0.55 & 0.22 \\
\hline C:N ratio & 44.18 & 71.64 & 196.36 \\
\hline Total phosphorous (\%) & 0.88 & 0.52 & 0.49 \\
\hline Total Potassium (\%) & 0.81 & 0.51 & 1.74 \\
\hline
\end{tabular}

Table.2 Influence of treatments on changes in $\mathrm{pH}$ and EC during composting

\begin{tabular}{|c|c|c|c|c|c|c|c|c|c|c|}
\hline \multirow[t]{3}{*}{ Treatments } & \multicolumn{5}{|c|}{ pH } & \multicolumn{5}{|c|}{$\mathrm{EC}\left(\mathrm{dSm}^{-1}\right)$} \\
\hline & \multicolumn{5}{|c|}{ Sampling period (days) } & \multicolumn{5}{|c|}{ Sampling period (days) } \\
\hline & Initial & 20 & 40 & 60 & Mean & Initial & 20 & 40 & 60 & Mean \\
\hline $\mathbf{T}_{1}$ & 7.9 & 7.8 & 7.7 & 7.7 & 7.78 & 0.86 & 0.92 & 1.65 & 1.17 & 1.15 \\
\hline $\mathbf{T}_{2}$ & 7.9 & 7.6 & 7.4 & 7.3 & 7.55 & 0.82 & 0.90 & 1.45 & 1.30 & 1.12 \\
\hline $\mathbf{T}_{\mathbf{3}}$ & 7.6 & 7.4 & 7.2 & 7.1 & 7.33 & 0.94 & 1.21 & 1.50 & 1.41 & 1.27 \\
\hline $\mathbf{T}_{4}$ & 7.8 & 7.6 & 7.3 & 7.2 & 7.48 & 0.86 & 0.98 & 1.30 & 1.25 & 1.10 \\
\hline $\mathbf{T}_{5}$ & 7.6 & 7.3 & 7.1 & 7.0 & 7.25 & 0.74 & 1.30 & 1.75 & 1.51 & 1.33 \\
\hline \multirow[t]{2}{*}{ Mean } & 7.76 & 7.54 & 7.34 & 7.26 & & 0.84 & 1.06 & 1.53 & 1.33 & \\
\hline & \multicolumn{3}{|c|}{ S.Ed } & \multicolumn{3}{|c|}{ C.D (0.05) } & \multicolumn{2}{|c|}{ S.Ed } & \multicolumn{2}{|c|}{ C.D (0.05) } \\
\hline D & \multicolumn{3}{|c|}{0.044} & \multicolumn{3}{|c|}{0.089} & \multicolumn{2}{|c|}{0.008} & \multicolumn{2}{|c|}{0.016} \\
\hline $\mathbf{T}$ & \multicolumn{3}{|c|}{0.050} & \multicolumn{3}{|c|}{0.099} & \multicolumn{2}{|c|}{0.007} & \multicolumn{2}{|c|}{0.014} \\
\hline $\mathbf{D} \times \mathbf{T}$ & \multicolumn{3}{|c|}{0.099} & \multicolumn{3}{|c|}{0.199} & \multicolumn{2}{|c|}{0.016} & \multicolumn{2}{|c|}{0.032} \\
\hline
\end{tabular}

Table.4 Influence of treatments on qualitative test and humification parameters of the compost

\begin{tabular}{|c|c|c|c|c|c|c|c|}
\hline Treatments & \multicolumn{2}{|c|}{ Qualitative test } & \multicolumn{5}{|c|}{ Humification parameters } \\
\hline & $\begin{array}{c}\text { Starch } \\
\text { iodine } \\
\text { test }\end{array}$ & $\begin{array}{c}\text { Sulphide } \\
\text { test }\end{array}$ & $\begin{array}{c}\text { Humic } \\
\text { acid } \\
(\%)\end{array}$ & $\begin{array}{c}\text { Fulvic } \\
\text { Acid } \\
(\%)\end{array}$ & $\begin{array}{c}\text { Degree of } \\
\text { humification } \\
(\%)\end{array}$ & $\begin{array}{c}\text { Humification } \\
\text { ratio }\end{array}$ & $\begin{array}{c}\text { Polymerization } \\
\text { ratio }\end{array}$ \\
\hline $\mathbf{T}_{\mathbf{1}}$ & + & - & 10.82 & 8.86 & 19.68 & 16.35 & $\mathbf{0 . 8 1}$ \\
\hline $\mathbf{T}_{\mathbf{2}}$ & + & - & 12.13 & 10.34 & 22.47 & 18.37 & $\mathbf{0 . 8 5}$ \\
\hline $\mathbf{T}_{\mathbf{3}}$ & + & - & 12.68 & 10.36 & 23.04 & 17.57 & $\mathbf{0 . 7 5}$ \\
\hline $\mathbf{T}_{\mathbf{4}}$ & + & - & 14.34 & 11.43 & 25.77 & 21.63 & $\mathbf{0 . 7 2}$ \\
\hline $\mathbf{T}_{\mathbf{5}}$ & + & - & 13.63 & 10.42 & 24.04 & 20.56 & $\mathbf{0 . 8 0}$ \\
\hline Mean & - & - & $\mathbf{1 2 . 7 2}$ & $\mathbf{1 0 . 2 8}$ & $\mathbf{2 3 . 0 0}$ & $\mathbf{1 8 . 9 0}$ & $\mathbf{0 . 7 9}$ \\
\hline S.Ed & - & - & $\mathbf{0 . 1 7}$ & $\mathbf{0 . 1 1}$ & $\mathbf{0 . 3 1}$ & $\mathbf{0 . 1 9}$ & $\mathbf{0 . 0 0 6}$ \\
\hline C.D $(\mathbf{0 . 0 5})$ & - & - & $\mathbf{0 . 3 7}$ & $\mathbf{0 . 2 3}$ & $\mathbf{0 . 6 8}$ & $\mathbf{0 . 4 3}$ & $\mathbf{0 . 0 1 3}$ \\
\hline
\end{tabular}


Table.5 Effect of different composts on the germination percentage and vigour index

\begin{tabular}{|c|c|c|c|c|c|c|c|c|}
\hline \multirow{3}{*}{ Treatments } & \multicolumn{4}{|c|}{ Tomato } & \multicolumn{4}{|c|}{ Cluster bean } \\
\hline & \multicolumn{2}{|c|}{$\begin{array}{l}\text { Length of } \\
\text { seedlings } \\
\text { (cm) }\end{array}$} & \multirow[t]{2}{*}{$\begin{array}{c}\text { Germination } \\
\%\end{array}$} & \multirow[t]{2}{*}{$\begin{array}{l}\text { Vigour } \\
\text { index }\end{array}$} & \multicolumn{2}{|c|}{$\begin{array}{l}\text { Length of } \\
\text { seedlings } \\
(\mathrm{cm})\end{array}$} & \multirow[t]{2}{*}{$\begin{array}{c}\text { Germination } \\
\%\end{array}$} & \multirow[t]{2}{*}{$\begin{array}{l}\text { Vigour } \\
\text { index }\end{array}$} \\
\hline & Root & Shoot & & & Root & Shoot & & \\
\hline $\mathbf{T}_{1}$ & 1.32 & 4.60 & 90 & 5.32 & 1.02 & 5.73 & 90 & 6.07 \\
\hline $\mathbf{T}_{2}$ & 1.67 & 5.74 & 92 & 6.81 & 1.74 & 5.80 & 92 & 6.94 \\
\hline $\mathbf{T}_{\mathbf{3}}$ & 3.01 & 9.00 & 98 & 11.76 & 2.90 & 8.00 & 98 & 10.68 \\
\hline $\mathbf{T}_{4}$ & 2.17 & 6.23 & 95 & 7.98 & 2.90 & 5.37 & 95 & 7.86 \\
\hline $\mathbf{T}_{5}$ & 3.50 & 10.14 & 100 & 13.90 & 3.05 & 9.80 & 100 & 12.85 \\
\hline Mean & 2.33 & 7.14 & 95.00 & 9.15 & 2.32 & 6.94 & 95.00 & 8.88 \\
\hline S.Ed & 0.038 & 0.133 & 1.475 & 0.147 & 0.033 & 0.095 & 1.569 & 0.122 \\
\hline C.D (0.05) & 0.084 & 0.290 & 3.213 & 0.320 & 0.072 & 0.206 & 3.419 & 0.266 \\
\hline
\end{tabular}

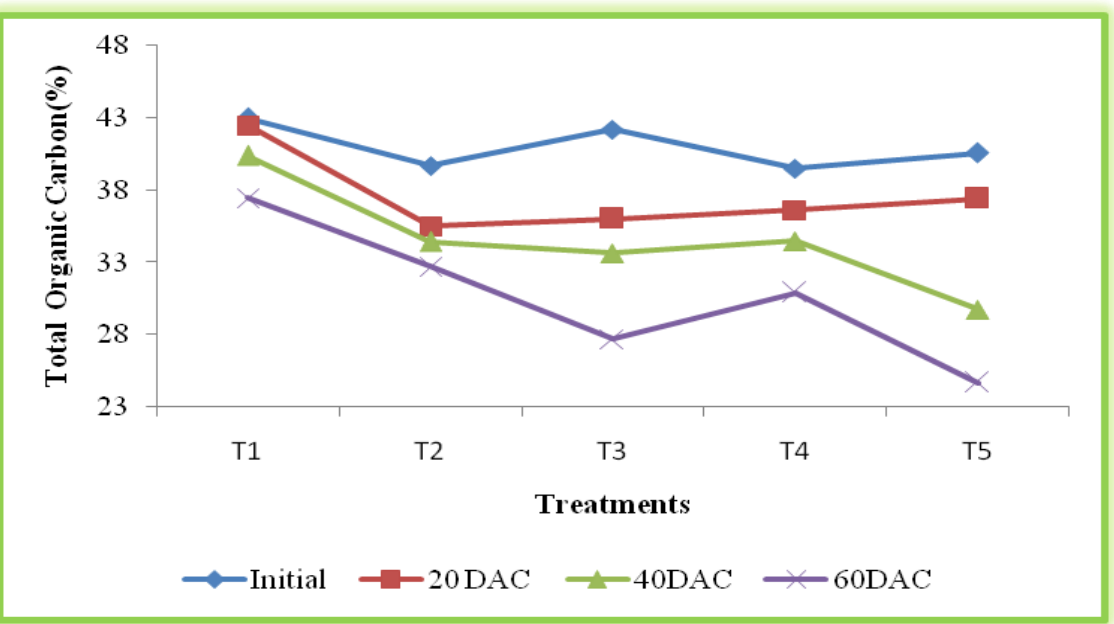

Figure.1 Influence of different treatments on total organic carbon levels during composting

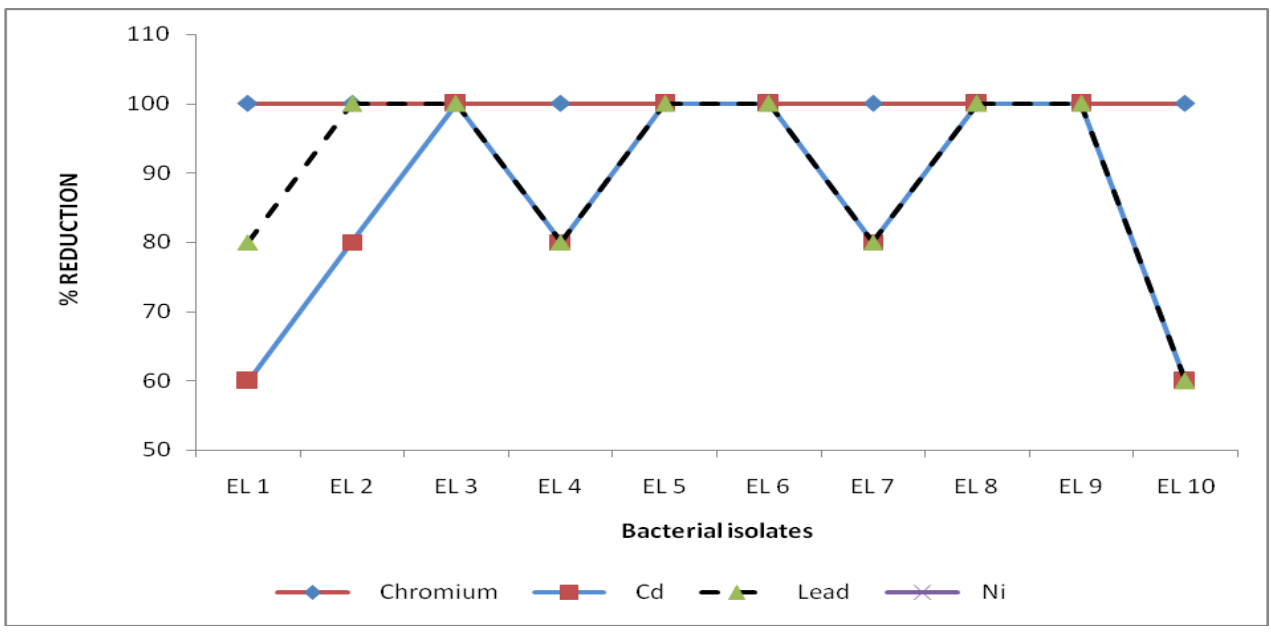

Figure.2 Influence of microbial culture on heavy metal reduction 
Table.3 Influence of treatments on changes in total kjeldahl nitrogen, total phosphorus and total potassium during composting

\begin{tabular}{|c|c|c|c|c|c|c|c|c|c|c|c|c|c|c|c|}
\hline \multirow{3}{*}{ Treatments } & \multicolumn{5}{|c|}{ TKN (\%) } & \multicolumn{5}{|c|}{ Total phosphorus (\%) } & \multicolumn{5}{|c|}{ Total potassium (\%) } \\
\hline & \multicolumn{5}{|c|}{ Sampling period (days) } & \multicolumn{5}{|c|}{ Sampling period (days) } & \multicolumn{5}{|c|}{ Sampling period (days) } \\
\hline & Initial & 20 & 40 & 60 & Mean & Initial & 20 & 40 & 60 & Mean & Initial & 20 & 40 & 60 & Mean \\
\hline $\mathbf{T}_{1}$ & 0.53 & 0.56 & 0.61 & 0.59 & 0.57 & 0.65 & 0.72 & 0.83 & 0.98 & 0.80 & 0.91 & 0.91 & 1.12 & 1.14 & 1.02 \\
\hline $\mathbf{T}_{2}$ & 0.56 & 0.71 & 1.15 & 0.92 & 0.84 & 0.63 & 0.79 & 0.93 & 1.19 & 0.89 & 0.87 & 0.94 & 1.24 & 1.27 & 1.08 \\
\hline $\mathbf{T}_{3}$ & 0.57 & 0.72 & 1.19 & 1.08 & 0.89 & 0.64 & 0.74 & 1.09 & 1.23 & 0.93 & 0.86 & 1.12 & 1.45 & 1.31 & 1.19 \\
\hline $\mathbf{T}_{4}$ & 0.52 & 0.69 & 1.17 & 1.01 & 0.85 & 0.68 & 0.82 & 1.07 & 1.22 & 0.95 & 0.89 & 1.21 & 1.33 & 1.27 & 1.18 \\
\hline $\mathbf{T}_{5}$ & 0.60 & 0.74 & 1.27 & 1.12 & 0.93 & 0.68 & 0.93 & 1.14 & 1.25 & 1.00 & 0.86 & 0.99 & 1.2 & 1.34 & 1.10 \\
\hline \multirow[t]{2}{*}{ Mean } & 0.56 & 0.68 & 1.08 & 0.94 & & 0.66 & 0.80 & 1.01 & 1.17 & & 0.88 & 1.03 & 1.27 & 1.27 & \\
\hline & \multicolumn{3}{|c|}{ S.Ed } & \multicolumn{2}{|c|}{ C.D (0.05) } & \multicolumn{3}{|c|}{ S.Ed } & \multicolumn{2}{|c|}{ C.D (0.05) } & \multicolumn{3}{|c|}{ S.Ed } & \multicolumn{2}{|c|}{ C.D (0.05) } \\
\hline D & \multicolumn{3}{|c|}{0.008} & \multicolumn{2}{|c|}{0.015} & \multicolumn{3}{|c|}{0.007} & \multicolumn{2}{|c|}{0.013} & \multicolumn{3}{|c|}{0.028} & \multicolumn{2}{|c|}{0.056} \\
\hline $\mathbf{T}$ & \multicolumn{3}{|c|}{0.007} & \multicolumn{2}{|c|}{0.014} & \multicolumn{3}{|c|}{0.006} & \multicolumn{2}{|c|}{0.012} & \multicolumn{3}{|c|}{0.025} & \multicolumn{2}{|c|}{0.050} \\
\hline $\mathbf{D} \times \mathbf{T}$ & \multicolumn{3}{|c|}{0.015} & \multicolumn{2}{|c|}{0.031} & \multicolumn{3}{|c|}{0.013} & \multicolumn{2}{|c|}{0.027} & \multicolumn{3}{|c|}{0.056} & \multicolumn{2}{|c|}{0.112} \\
\hline
\end{tabular}

Table.6 Morphological and biochemical characterization of bacterial isolates

\begin{tabular}{|c|c|c|c|c|c|c|c|c|c|c|c|c|c|c|}
\hline \multirow{2}{*}{$\begin{array}{c}\text { Sl.N } \\
\text { o }\end{array}$} & \multirow{2}{*}{$\begin{array}{l}\text { Isolate } \\
\text { name }\end{array}$} & \multicolumn{2}{|c|}{ Morphological } & \multicolumn{2}{|c|}{ Colony } & \multicolumn{8}{|c|}{ Biochemical characterization } & \multirow{2}{*}{$\begin{array}{c}\text { Tentative } \\
\text { identification }\end{array}$} \\
\hline & & $\begin{array}{c}\text { Gram } \\
\text { reaction }\end{array}$ & Shape & Morphology & Color & $\mathbf{G}$ & $\mathbf{S}$ & $\mathbf{L}$ & GH & SH & $\mathbf{C U}$ & Indole & CT & \\
\hline 1 & EL 1 & - & Round & Rod & White & A & A & A & - & + & + & - & + & NI \\
\hline 2 & EL2 & - & Round & Rod & Yellow & A & A & A & + & - & + & - & + & Xanthomonassp. \\
\hline 3 & EL3 & - & Round & Rod & Cream & A & A & A & + & + & + & + & + & $\begin{array}{c}\text { Pseudomonas } \\
\text { fluorescens }\end{array}$ \\
\hline 4 & EL4 & - & Round & Cocci & Yellow & $\mathrm{A} / \mathrm{G}$ & A & A & + & - & + & + & + & Enterobactersp. \\
\hline 5 & EL5 & + & Wrinkled & Rod & Cream & A & A & $\mathrm{A} / \mathrm{G}$ & - & - & + & + & + & Bacillussp. \\
\hline 6 & EL6 & - & Round & Rod & Cream & A & A & A & + & - & + & + & + & Pseudomonassp. \\
\hline 7 & EL7 & - & Round & Rod & Cream & $\mathrm{A} / \mathrm{G}$ & $\mathrm{A} / \mathrm{G}$ & $\mathrm{A} / \mathrm{G}$ & - & + & + & - & + & NI \\
\hline 8 & EL8 & - & Round & Rod & Cream & A & A & A & + & + & + & - & + & Pseudomonassp. \\
\hline 9 & EL9 & + & Wrinkled & Rod & Pink & A & A & $\mathrm{A} / \mathrm{G}$ & - & - & + & + & + & Bacillussp. \\
\hline 10 & EL10 & - & Round & Rod & Cream & $\mathbf{A}$ & $\mathbf{A}$ & $\mathbf{A}$ & - & + & + & - & + & NI \\
\hline
\end{tabular}

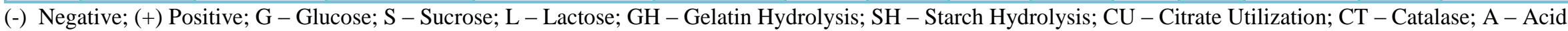
production; G - Gas production; NI - Not Identified 


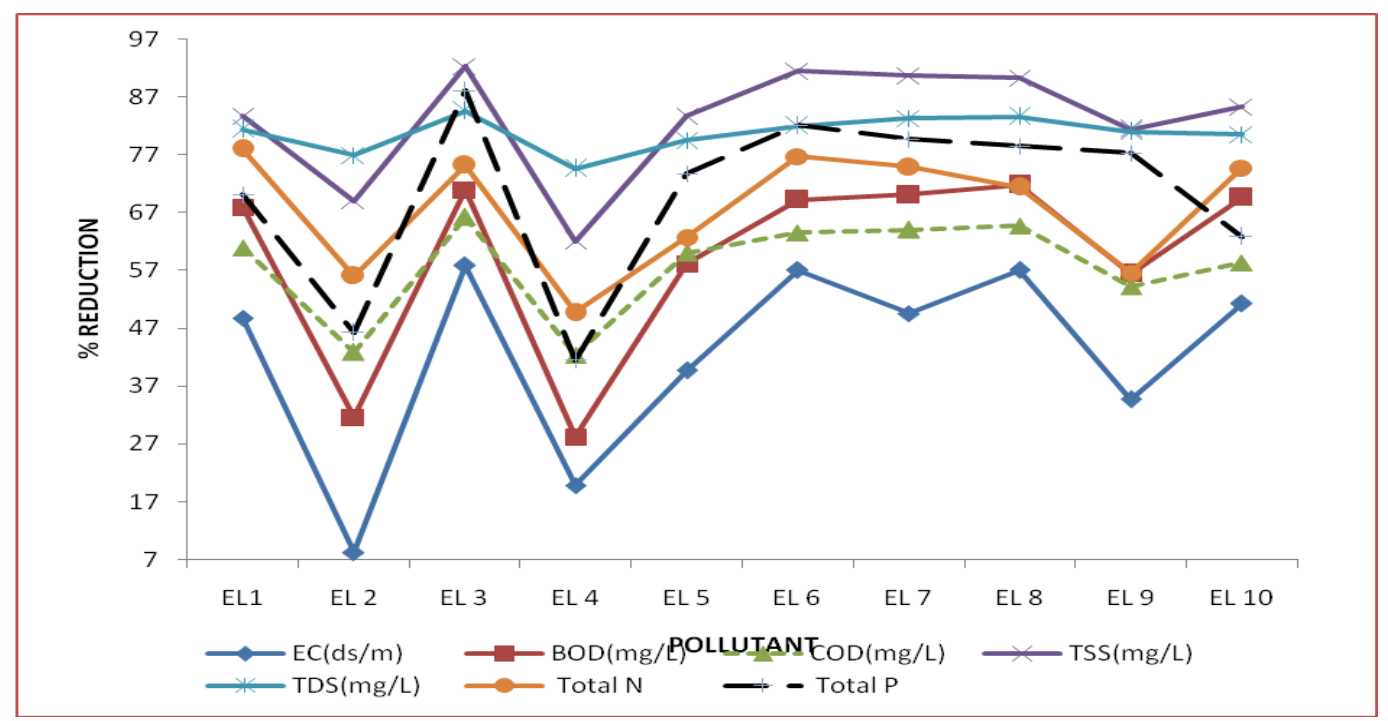

Figure.3 Influence of microbial culture on pollution reduction

The present investigation revealed that cocomposting of water hyacinth + crop residues + cow dung in the ratio of 1:1:1 with the supplementation of Pleurotus+ E.eugeniae could yield the manure of higher nutrient content. Also, mediates the optimal physicochemical characters towards the growth of crops like cluster bean and tomato.

Hence, it can be recommended to co-compost water hyacinth biomass with crop residues and cow dung in supplementation with Pleurotus + E. eugeniae for getting quality manure in this era of higher price of fertilizers and to keep the growth of the noxious weed, water hyacinth under check. By effective bioremediation with the bacterial isolate (Pseudomonas fluorescens), all the heavy metals concentration got reduced below the desirable limit. Hence, the potential of this organism may be utilised through biostimulation process to restore the eutrophicated lakes.

\section{References}

Abbasi,S.A. and E.V.Ramasamy. 1999. Biotechnological Methods of Pollution Control. P. 168.

APHA. 1980. Standard methods for the examination of water and wastewater, $16^{\text {th }}$ edition. American public health association, Washington, DC.

Batham,M., R.Arya and A.Tiwari. 2014. Time efficient co-composting of water hyacinth and industrial waste by microbial degradation and subsequent vermicomposting. Journal of Bioremediation and Biodegradation, 5(3): 1-10.

Buchanan,R. E. and N.R. Gibbons. 1974. Bergey's Manual of Determinative Bacteriology, $8^{\text {th }}$ ed., Williams \& Wilkins.Baltimore.

Campell, A.G., R.L. Folk and R.R. Tripepi. 1997. Wood ash as an amendment in municipal sludge and yard composting processes, Compost Science \& Utilization, 5(1): 62-73.

Elango, D., N. Thinakaran, P. Panneerselvam and S. Sivanesan. 2009. Thermophilic composting of municipal solid waste. Applied Energy, 86(5): 663-668.

Jenson,V. 1968. The plate counts method. In:Proceedings of International Symposium on the Ecology of soil Bacteria. (Eds.) T.R.G. Gray and P.ParkinsonLiver pool University Press, Liverpool, pp: 158-170.

Kapanen, A. and M. Itavaara. 2001. 
Ecotoxicity tests for compost applications. Ecotoxicol. Environ. Safety, 9(1): 1-16.

Murugesan, A.G., J.Ruby, M.G. Paulraj and N.Sukumaran. 2005. Impact of different densities and temperature regimes on the feeding behaviour of water hyacinth weevils, Necochetina Bruchi and Neochetinaeichhorniae on Eichhornia crassipes. Asian Journal of Microbial Biotechnology and Environmental Sciences, 7(1): 73-76.

Nallathambi, P. and T. Marimuthu. 1993. Pleurotus platypus: A potent oyster mushroom for organic recycling of agricultural wastes. Mushroom Resource, 2: 75-77.

Parameswari, E. (2009). Impact of agricultural drainage water on crops under sequential biological concentration system and use of nanoparticles for wastewater treatment (Doctoral dissertation, Ph. D. Thesis, Tamil Nadu Agric. Univ., Coimbatore).

Rao,J.R., M.Watobe, T.A.Stewart, B.C.Millar and J.E.Moore, 2007. Pelleted organomineral fertilizer from composited pig slurry solids, animal wastes and spent mushroom compost for amenity grasslands. Waste management, 27 (9): 1119-1128.

Suthar, S. 2007. Nutrient changes and biodynamics of epigeic earthworm Perionyx excavatus (Perrier) during recycling of some agriculture wastes. Bioresource Technology., 98, 16081614.

\section{How to cite this article:}

Prithiv Raj. V, T. Ilakiya, E. Parameswari and Davamani. V. 2020. Assessment of New Ecotechnological Measures to Restore the Eutrophicated Lake. Int.J.Curr.Microbiol.App.Sci. 9(03): 1457-1466. doi: https://doi.org/10.20546/ijcmas.2020.903.170 